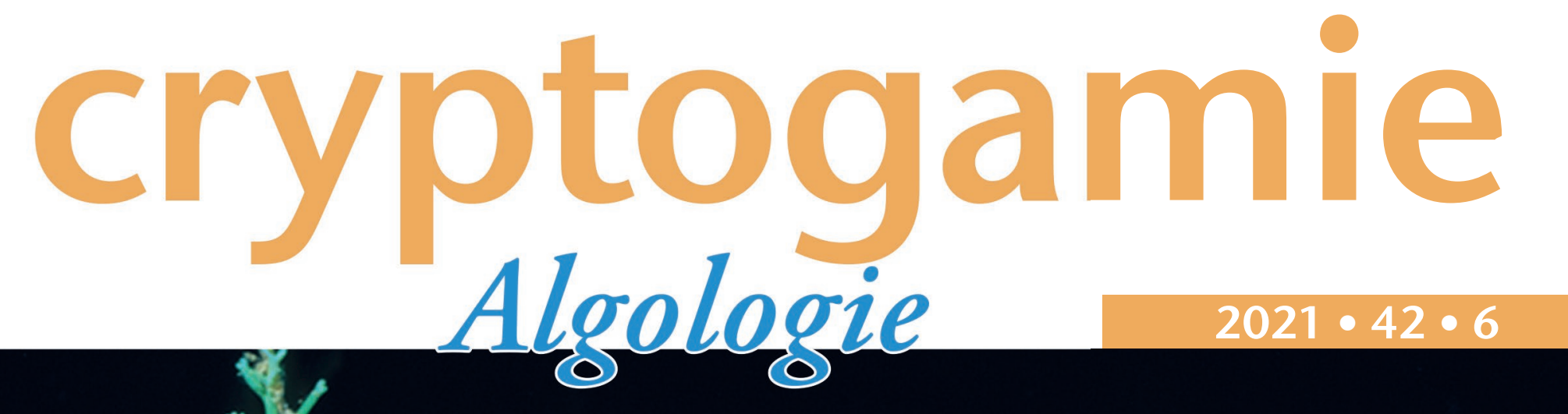

the canopy-forming alga Ericaria brachycarpa 2,4

(N) Agardh) Molinari-Noyoa \& Guiry (Fucales, Pháaphyceae) shows seasonal and - depthadaptation to the incoming light levels

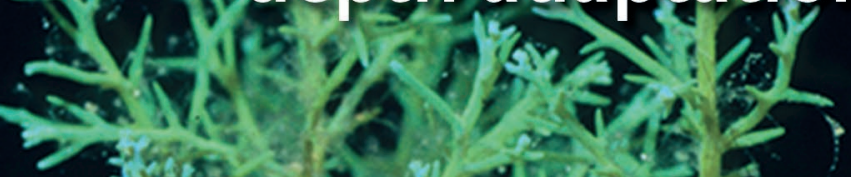

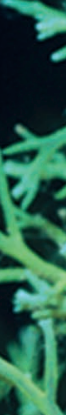

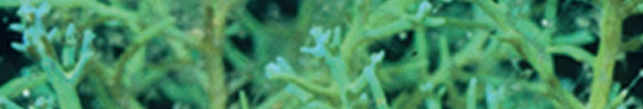
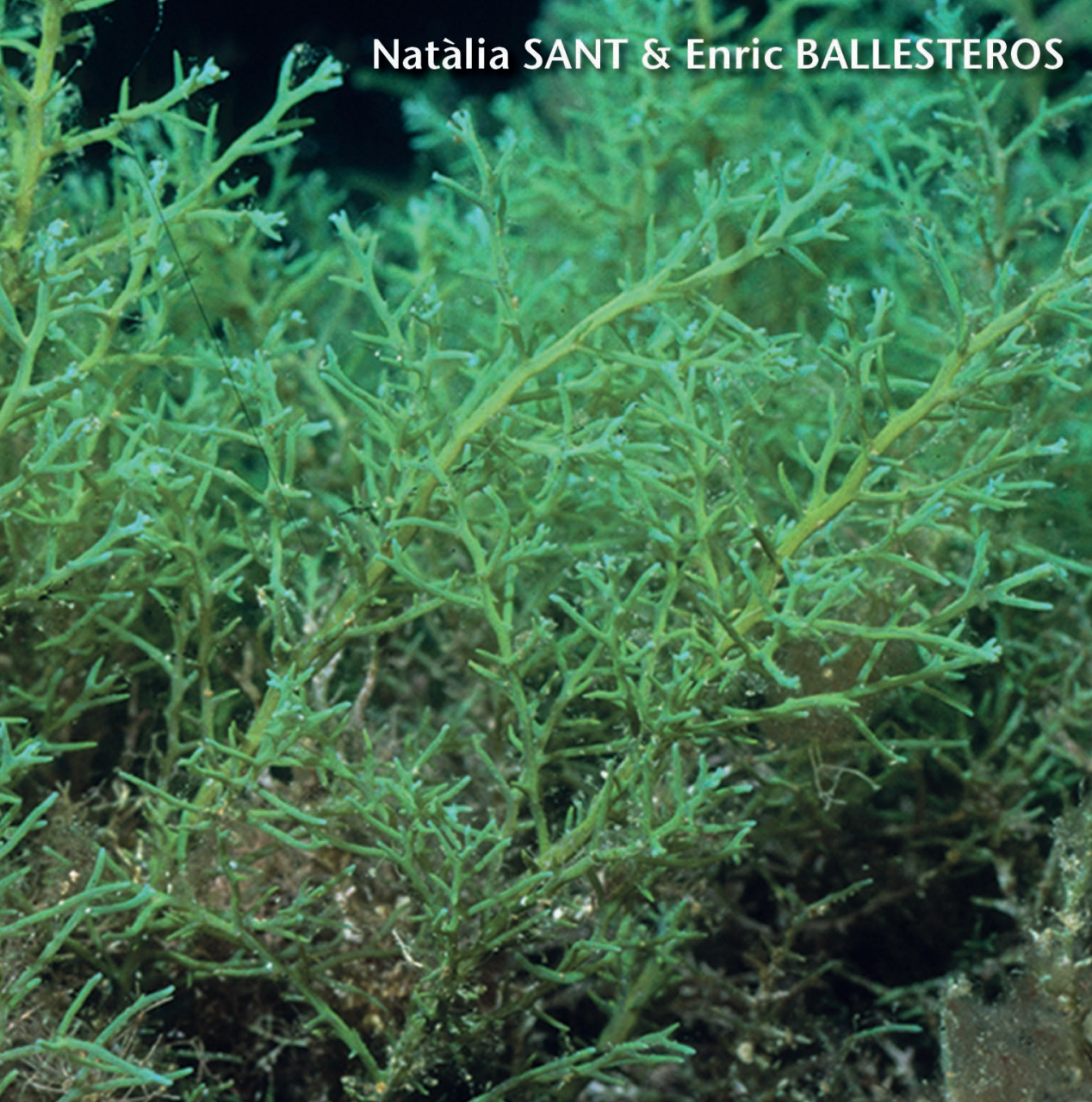
DiRECTEUR DE LA PUBLICATION / PUBLICATION DIRECTOR: Bruno DAVID

Président du Muséum national d'Histoire naturelle

RÉDACTRICE EN CHEF / EDITOR-IN-CHIEF : Line LE GALL

Muséum national d'Histoire naturelle

ASSISTANTE DE RÉDACTION / AsSISTANT EDITOR : Marianne SALAÜN (algo@cryptogamie.com)

MISE EN PAGE / PAGE LAYOUt : Marianne SALAÜN

RÉDACTEURS ASSOCIÉs / AsSOCIATE EDITORS

Ecoevolutionary dynamics of algae in a changing world

Stacy KRUEGER-HADFIELD

Department of Biology, University of Alabama, 1300 University Blvd, Birmingham, AL 35294 (United States)

Jana KULICHOVA

Department of Botany, Charles University, Prague (Czech Republic)

Cecilia TOTTI

Dipartimento di Scienze della Vita e dell'Ambiente, Università Politecnica delle Marche, Via Brecce Bianche, 60131 Ancona (Italy)

Phylogenetic systematics, species delimitation \& genetics of speciation

Sylvain FAUGERON

UMI3614 Evolutionary Biology and Ecology of Algae, Departamento de Ecología, Facultad de Ciencias Biologicas,

Pontificia Universidad Catolica de Chile, Av. Bernardo O’Higgins 340, Santiago (Chile)

Marie-Laure GUILLEMIN

Instituto de Ciencias Ambientales y Evolutivas, Universidad Austral de Chile, Valdivia (Chile)

Diana SARNO

Department of Integrative Marine Ecology, Stazione Zoologica Anton Dohrn, Villa Comunale, 80121 Napoli (Italy)

Comparative evolutionary genomics of algae

Nicolas BLOUIN

Department of Molecular Biology, University of Wyoming, Dept. 3944, 1000 E University Ave, Laramie, WY 82071 (United States)

Heroen VERBRUGGEN

School of BioSciences, University of Melbourne, Victoria, 3010 (Australia)

Algal physiology \& photosynthesis

Janet KÜBLER

California State University Northridge, Department of Biology, California State University, Northridge, CA 91330-8303 (United States)

Prokaryotic algae

Nico SALMASO

IASMA Research and Innovation Centre, Fondazione Mach-Istituto Agrario di S. Michele all'Adige, Limnology and River Ecology,

Via E. Mach, 1, 38010 San Michele all'Adige, Trento (Italy)

Vitor VASCONCELOS

Faculdade de Ciências da Universidade do Porto and CIIMAR, Rua do Campo Alegre, s/n, 4169-007 Porto (Portugal)

COUVERTURE / COVER:

Ericaria brachycarpa (J.Agardh) Molinari-Novoa \& Guiry

Cryptogamie, Algologie est indexé dans / Cryptogamie, Algologie is indexed in:

- Aquatic Sciences \& Fisheries Abstracts Part I.

- Biological Abstracts

- Chemical Abstracts

- Current Contents

- Marine Science Contents Tables (FAO)

- Science Citation Index

- Publications bibliographiques du CNRS (Pascal).

Cryptogamie, Algologie est distribué en version électronique par / Cryptogamie, Algologie is distributed electronically by:

- BioOne ${ }^{\circledR}$ (http://www.bioone.org/loi/crya)

Cryptogamie, Algologie est une revue en flux continu publiée par les Publications scientifiques du Muséum, Paris

Cryptogamie, Algologie is a fast track journal published by the Museum Science Press, Paris

Les Publications scientifiques du Muséum publient aussi / The Museum Science Press also publishes: Adansonia, Geodiversitas, Zoosystema, Anthropozoologica, European Journal of Taxonomy, Naturae, Comptes Rendus Palévol, Cryptogamie sous-sections Bryologie, Mycologie.

Diffusion - Publications scientifiques Muséum national d'Histoire naturelle

CP $41-57$ rue Cuvier F-75231 Paris cedex 05 (France)

Tél. : 33 (0)1 40794805 / Fax: 33 (0)1 40793840

diff.pub@mnhn.fr / http://sciencepress.mnhn.fr

(c) Publications scientifiques du Muséum national d'Histoire naturelle, Paris, 2021

ISSN (imprimé / print): 0181-1568 / ISSN (électronique / electronic): 1776-0984 


\title{
The canopy-forming alga Ericaria brachycarpa (J.Agardh) Molinari-Novoa \& Guiry (Fucales, Phaeophyceae) shows seasonal and depth adaptation to the incoming light levels
}

\author{
Natàlia SANT \\ Enric BALLESTEROS \\ Centre d'Estudis Avançats de Blanes-CSIC. Acc. \\ Cala Sant Francesc 14. 17300 Blanes, Girona (Spain) \\ kike@ceab.csic.es (corresponding author)
}

Submitted on 10 June 2020 | Accepted on 1 February 2021 | Published on 28 April 2021

KEY WORDS

Photosynthesis, Ericaria brachycarpa,
depth, adaptation, primary productivity.

MOTS CLÉS

Photosynthèse,

Ericaria brachycarpa,

profondeur

adaptation,

productivité primaire.
Sant N. \& Ballesteros E. 2021. - The canopy-forming alga Ericaria brachycarpa (J.Agardh) Molinari-Novoa \& Guiry (Fucales, Phaeophyceae) shows seasonal and depth adaptation to the incoming light levels. Cryptogamie, Algologie 42 (6): 67-75. https://doi.org/10.5252/cryptogamie-algologie2021v42a6. http://cryptogamie.com/algologie/42/6

\section{ABSTRACT}

The shallow water canopy-forming alga Ericaria brachycarpa (J.Agardh) Molinari-Novoa \& Guiry shows higher photosynthetic efficiency $(\alpha)$, maximum photosynthetic rates $\left(\mathrm{P}_{\max }\right)$, light at compensation $\left(I_{c}\right)$ and dark respiration $\left(R_{d}\right)$ in individuals collected at the lower depth limit of distribution of the species $(20 \mathrm{~m})$ than at shallower depths $(2$ and $10 \mathrm{~m})$. Photosynthesis at saturation light levels $\left(\mathrm{P}_{\text {sat }}\right)$ does not change in crossed transplants from 3 to 20 and from 20 to $3 \mathrm{~m}$ neither after 11 or 90 days. However, production at low light levels $\left(\mathrm{P}_{\mathrm{b}}\right)$ increased in transplants from 3 to $20 \mathrm{~m}$ and decreased in transplants from 20 to $3 \mathrm{~m}$ after 90 days. Photosynthesis, both at high and low light levels increased from June to September. Seasonality explained most of the variance $(70 \%)$ in the values of $\mathrm{P}_{\text {sat }}$, whilst transplantation explained $47 \%$ of the variance for $\mathrm{P}_{\mathrm{b}}$ and $\mathrm{R}_{\mathrm{d}}$. Thus, E. brachycarpa is able to adapt its photosynthetic performances across its depth distribution limits and easily cope with sudden variations in the light environment associated or not with seasonality.

\section{RÉSUMÉ}

L'algue formant une canopée Ericaria brachycarpa (J.Agardh) Molinari-Novoa \& Guiry (Fucales, Phaeophyceae) montre une adaptation à la profondeur et une adaptation saisonnière aux valeurs de lumière disponible. L'algue d'eau peu profonde formatrice de canopée Ericaria brachycarpa (J.Agardh) Molinari-Novoa \& Guiry montre une majeure efficience photosynthétique $(\alpha)$, photosynthèse maximale $\left(P_{\max }\right)$, lumière à la compensation $\left(I_{c}\right)$ et respiration sombre $\left(R_{d}\right)$ pour des individus collectés dans la limite la plus profonde de la bathymétrique de l'espèce $(20 \mathrm{~m})$ qu'à des profondeurs moindres (2 et $10 \mathrm{~m})$. La photosynthèse en saturation $\left(\mathrm{P}_{\text {sat }}\right)$ ne change pas dans des transplants croisés entre 3 et 20 mètres après 11 ou 90 jours. Néanmoins, la production à une basse lumière $\left(\mathrm{P}_{\mathrm{b}}\right)$ augmente dans les transplants de 3 à $20 \mathrm{~m}$ et diminue dans les transplants de 20 à $3 \mathrm{~m} 90$ jours après la transplantation. La photosynthèse, tant pour les lumières hautes que pour les basses, augmente depuis juin à septembre. La variation saisonnière explique la plupart de la variance $(70 \%)$ dans les données de $\mathrm{P}_{\text {sat }}$ tandis que la transplantation explique les $47 \%$ de la variance pour $\mathrm{P}_{\mathrm{b}}$ and $\mathrm{R}_{\mathrm{d}}$. Ainsi, E. brachycarpa peut adapter ses performances photosynthétiques dans ses limites de distribution en profondeur et peut facilement faire face à des variations de lumière qui sont associés ou non aux conditions saisonnières. 


\section{INTRODUCTION}

The photosynthetic response of aquatic macrophytes to the light intensity partially determines the habitats where they can thrive, together with other factors such as nutrient availability, hydrodynamism, environmental variability and biological interactions (Zabala \& Ballesteros 1989; Witman \& Dayton 2001; Vergés et al. 2009). Light intensity decreases with depth (Ballesteros \& Zabala 1993; Kirk 1994) and determines the depth distribution limit of most aquatic macrophytes (Kirk 1994). Moreover, the depth distribution of aquatic macrophytes seems to be related to their photosynthetic features. According to Sant \& Ballesteros (2020) deep-water species show higher photosynthesis at low light levels, higher photosynthesis at saturation, and lower light at compensation than shallow water species.

However, the results provided by Sant \& Ballesteros (2020) are based on studies performed at the species level. No tests have been performed for specimens of the same species collected at their upper, medium and lower depth distribution ranges and thus we still do not know which is the ability of each species to adapt its photosynthetic features to its light environment. In the case that adaptation exists, a species should be able to adjust its photosynthetic system in the same way that is performed by the different species living at different depths, i.e. increasing both photosynthetic efficiency and maximum photosynthetic yields. If depth-related intraspecific differences occur, another question that remains opened is the time -days to weeks- that the photosynthetic system needs to readjust its properties according to the new light environment. This specially concerns perennial species in temperate ecosystems since the light environment not only changes with depth but also with season (Weinberg \& Cortel-Breeman 1978; Ballesteros 1989).

In order to address these issues, here we 1) compare the photosynthetic features of specimens of the same species of macroalga living at different light levels; and 2) look at the adjustment of the photosynthesis/light patterns through time by transplanting specimens both from deep to shallow and from shallow to deep waters. These questions are also relevant in the frame of the rapid environmental changes that are being experienced in coastal areas subjected to different anthropogenic pressures, which reduce light transmittance in the water column.

\section{MATERIAL AND METHODS}

The selected species is Ericaria brachycarpa (J.Agardh) Molinari-Novoa \& Guiry (Molinari-Novoa \& Guiry 2020) [syn. Cystoseira balearica Sauvageau, Carpodesmia brachycarpa (J.Agardh) S. Orellana \& M. Sansón], a perennial species with caespitose erect cauloids up to $15 \mathrm{~cm}$ long, covered by cylindric branches with some scattered spinose appendages (Cormaci et al. 2012; Rodríguez-Prieto et al. 2013). Ericaria brachycarpa is a species endemic to the Mediterranean, being present in the Western Mediterranean (Verlaque 1987; Hoff- mann et al. 1992; Gómez-Garreta et al. 1994; Ribera et al. 1995; Sales \& Ballesteros 2009; Thibaut et al. 2016) and the Aegean Sea (Huvé 1972; Montesanto \& Panayotidis 2000; Cocito et al. 2000; Catra \& Giardina 2009; Giakoumi et al. 2012; Taskin et al. 2012) but it seems to be absent on other Mediterranean areas like the Adriatic (Ercegovic 1952; Ivesa et al. 2016) or the Levantine Sea (Lakkis \& Novel-Lakkis 2000; Einav \& Israel 2008). Ericaria brachycarpa can make underwater forests which host a huge diversity of organisms (Coppejans \& Boudouresque 1975; Verlaque 1987; Thiriet et al. 2016; Piazzi et al. 2018) and have a high nursery value for some coastal fishes (Cheminée et al. 2013, 2017). These forests are mainly distributed in shallow environments, down to $20 \mathrm{~m}$ depth (Giaccone 1973; Verlaque 1987; Ballesteros et al. 2002; Sant 2003) and although the species is rather resistant to herbivory by fish (Vergés et al. 2009), it is highly consumed by the sea urchin Paracentrotus lividus (Lamarck, 1816) which can decrease its abundance and even create barrens (Verlaque 1987; Ballesteros et al. 2002; Thibaut $e t$ al. 2016; Piazzi \& Ceccherelli 2017). Although it is rather resilient (Piazzi et al. 2017; Tamburello et al. 2019) the species is considered threatened by the Barcelona Convention (UNEP/MAP 2009; Verlaque et al. 2019).

Sampling site was located at Illa des Porros, an islet situated at the northernmost tip of Menorca (Balearic Islands, Western Mediterranean) $\left(40^{\circ} 05^{\prime} 33^{\prime \prime} \mathrm{N}, 4^{\circ} 04^{\prime} 39^{\prime \prime} \mathrm{E}\right)$. The shallow area, between 2 and $15 \mathrm{~m}$ depth, is dominated by a forest of E. brachycarpa, with some specimens descending down to $22 \mathrm{~m}$, where it grows mixed with other species in a community dominated by Dictyopteris polypodioides (A.P. De Candolle) J.V. Lamouroux.

Sampling was performed using SCUBA. Three depths were selected (3,10 and $20 \mathrm{~m})$ and the specimens collected to perform the experiments come from these depths. The abundance of $E$. brachycarpa was quantified by deploying fifty $25 \mathrm{~cm} \times 25 \mathrm{~cm}$ quadrats divided into 25 subquadrats of $5 \mathrm{~cm} \times 5 \mathrm{~cm}$ at each of the selected depths. The percentage of subquadrats in which E. brachycarpa appeared was recorded and used as a measure of occurrence (Sala \& Ballesteros 1997; Tomas et al. 2011; Sant et al. 2017).

A first set of experiments was addressed to perform the photosynthesis/light intensity curves of individuals living at 3, 10 and $20 \mathrm{~m}$ depth, following procedures explained in Sant \& Ballesteros (2020). These experiments were performed only in June. Specimens of E. brachycarpa were collected during late afternoon every day at each of the selected depths. Specimens were maintained overnight submerged at sea inside mesh bags and protected from direct light until next morning.

A second set of experiments involved the collection of 40 specimens of E. brachycarpa, 20 from $3 \mathrm{~m}$ and 20 from $20 \mathrm{~m}$. Ten specimens of each depth were transplanted at the depth where they came from 3 to 3 (3to3) and 20 to 20 (20to20) and the other 10 were transplanted at the other depth [3 to 20 (3to20) and 20 to 3 (20to3)]. Transplantation took place at mid June. All specimens were transplanted the same day of collection and fixed again to the rock by means of a two-component non-toxic epoxy glue (IVEGOR $\left.{ }^{\circ}\right)($ Cebrian 
et al. 2006; Sales et al. 2011). The production of oxygen at saturation light levels $\left(\mathrm{P}_{\text {sat }}\right)$, production of oxygen at low light levels $\left(\mathrm{P}_{\mathrm{b}}\right)$ and dark respiration $\left(\mathrm{R}_{\mathrm{d}}\right)$ was measured for control specimens (non transplanted, nt3 and nt20) at the day of transplantation (0), 11 days after transplantation (11) and 90 days after transplantation (90). The same measures were performed for transplant controls and transplants at 11 (June) and 90 days after transplantation (September). Branches of the control and transplanted specimens were collected during late afternoon the day before the assays were performed, at each depth and maintained overnight submerged at sea inside mesh bags and protected from direct light until next morning.

Branches were sorted and prepared for photosynthesis and respiration assays in the early morning just before the experiments began (Sant \& Ballesteros 2020). Material selection, manipulation and assays were performed according to the recommendations made by Littler (1979), Littler \& Arnold (1980) and Littler \& Littler (1985). Photosynthesis assays were performed in $270 \mathrm{~mL}$ glass bottles. Apical branches with a length of $2-3 \mathrm{~cm}$ were selected among the collected material, cleaned of macroepiphytes with small forceps, and introduced in the glass bottles containing seawater and a glass marble hanging inside the bottle and subjected with a nylon line. Only one to two branches were introduced at every bottle. The bottles with the algal specimens were hung in a structure hanging from a buoy and placed in the sea at Fornells Bay, nearby the sampling station, at $2 \mathrm{~m}$ depth. Waves moved the structure and the glass marbles shook the water inside the bottle, breaking diffusion gradients.

For the first set of experiments, four replicated bottles per depth $(3,10$ and $20 \mathrm{~m}$ ) and four empty bottles (to account for variation not due to macroalgae) were assayed every day at a different photon flux density (PFD) making a total of 16 assays per day. Nine different PFDs were obtained by covering the structure with a different number of neutral filters, using a black filter to measure dark respiration. Ambient light in each assay was measured using a spherical sensor Li-1000 SPQA deployed at the same site and depth of the hanging structure. PFD attenuation inside the hanging structure with increasing number of filters was also measured $\left(y=100 \mathrm{e}^{-0.52 x}, \mathrm{R}^{2}=0.99\right.$, $\mathrm{x}=$ number of neutral filters, $\mathrm{y}=\%$ ambient PFD). Light intensities ranged between 0 and $2100 \mu \mathrm{mol}$ photon $\mathrm{m}^{-2} \mathrm{~s}^{-1}$.

In the second set of experiments $\mathrm{P}_{\text {sat }}$ values were measured at mean PFDs of $1762 \mu \mathrm{mol}$ photon $\mathrm{m}^{-2} \mathrm{~s}^{-1}$ in June and 1243 $\mu \mathrm{mol}$ photon $\mathrm{m}^{-2} \mathrm{~s}^{-1}$ in September, $\mathrm{P}_{\mathrm{b}}$ values were estimated for mean PFDs of $119 \mu \mathrm{mol}$ photon $\mathrm{m}^{-2} \mathrm{~s}^{-1}$ in June and 106 $\mu \mathrm{mol}$ photon $\mathrm{m}^{-2} \mathrm{~s}^{-1}$ in September. We also tested that the different incubation PFDs between the days of the experiment was low enough not to interfere significantly on the results (regression analysis, $\mathrm{p}>0.05$ ). $\mathrm{R}_{\mathrm{d}}$ was measured as in the first set of experiments.

Incubation times ranged between 3 and 4 hours and assays were always performed between 10:00 am and 2:00 pm. Each branch was used only once, which made every assay independent from the others. Oxygen was measured after the assay with an Oxygen Analyzer Orbisphere 2607 with an accuracy of $0.01 \mathrm{mg} \mathrm{O}_{2} \mathrm{l}^{-1}$. Oxygen production/dark consumption was measured as the difference between the oxygen from each bottle containing a specimen and the average of the four empty bottles. Specimens used in the assays were dried at $60^{\circ} \mathrm{C}$ for 48 hours to obtain their dry weight (DW) (Boudouresque 1971; Romero 1981; Ballesteros 1986). The specimens were then burned in an oven for $4 \mathrm{~h}$ at $500^{\circ} \mathrm{C}$ to obtain the ash free dry weight (AFDW; Brinkhuis 1985).

In the first set of experiments the data obtained in the assays was pooled together to obtain the photosynthesis/light intensity (PFD) curves. We did not adjust any function to the curves due to the existence of different models (see Jones et al. 2014 for a discussion). Alternatively, we have obtained the different photosynthetic parameters directly based on photosynthesis at saturation levels $\left(\mathrm{P}_{\max }\right)$ and variation of photosynthesis at low light levels (photosynthetic efficiency, a) (Arenas et al. 1995; Gómez et al. 1996; Gómez \& Wiencke 1997), which allows comparisons within our data. The photosynthetic parameters finally obtained were dark respiration $\left(R_{d}\right.$ in $\mathrm{mg} \mathrm{O}_{2}$. AFDW-1.h $^{-1}$ ), light at compensation $\left(\mathrm{I}_{\mathrm{c}}\right.$ in $\mu \mathrm{mol}$ photon $\left.\cdot \mathrm{m}^{-2} \cdot \mathrm{s}^{-1}\right)$, photosynthetic efficiency $\left[\alpha\right.$ in $\mathrm{mg} \mathrm{O}_{2} \cdot \mathrm{m}^{2} \mathrm{~s}$ ( $\mu$ mol photon.gAFDW.h)-1], light at saturation levels $\left(\mathrm{I}_{\mathrm{k}}\right.$ in $\mu \mathrm{mol}$ photon $\left.\cdot \mathrm{m}^{-2} \cdot \mathrm{s}^{-1}\right)$, and photosynthesis at saturation levels $\left(\mathrm{P}_{\max }\right.$ in $\mathrm{mg} \mathrm{O}_{2}$. gAFDW-1. $^{-1}$ ).

Nutrient content in tissues was measured from specimens collected at the depths of 3,10 and $20 \mathrm{~m}$ during the first set of experiments. The samples were frozen after collection and on arrival in the laboratory they were defrosted, dried and triturated. Carbon and nitrogen were measured with a CarloErba Autoanalyzer (Serveis Científico-Tècnics, University of Barcelona) and phosphorus was analysed with an inductively coupled plasma mass spectrometer (ICP) after acid digestion of the samples, following Mateo \& Sabaté (1993).

Differences between $\mathrm{P}_{\max }$ and $\mathrm{R}_{\mathrm{d}}$ between depths were tested with a one-way ANOVA followed by a Tukey test. To compare the lineal part of the photosynthesis/PFD curves $(\alpha)$ a twoway (species and light) ANOVA followed by a Tukey test was used. Data was log-transformed in order to accomplish the assumptions of ANOVA. Relationships between parameters were estimated using Pearson lineal correlations.

Differences in $\mathrm{P}_{\text {sat }}$ and $\mathrm{P}_{\mathrm{b}}$ were tested with ANOVA using factors "transplant" and "time", where "transplant" is the kind of transplant applied and "time" is the length of the experiment in days. When there was a significant correlation between mean values and their variances, or data did not follow normality, data was transformed to accomplish ANOVA assumptions. When ANOVAs were significant $(\mathrm{p}<0.05)$ means were compared using Tukey tests. Mean values of "transplant controls" were compared with controls (non transplanted specimens) from the same depth by means of t-Student tests. All statistical analysis were performed using SYSTAT® (SPSS Inc.).

\section{RESULTS}

The abundance of E. brachycarpa decreases with depth (Fig. 1), being dominant between 3 and $10 \mathrm{~m}$ and showing a low abundance at $20 \mathrm{~m}$. The photosynthesis/PFD curves from 


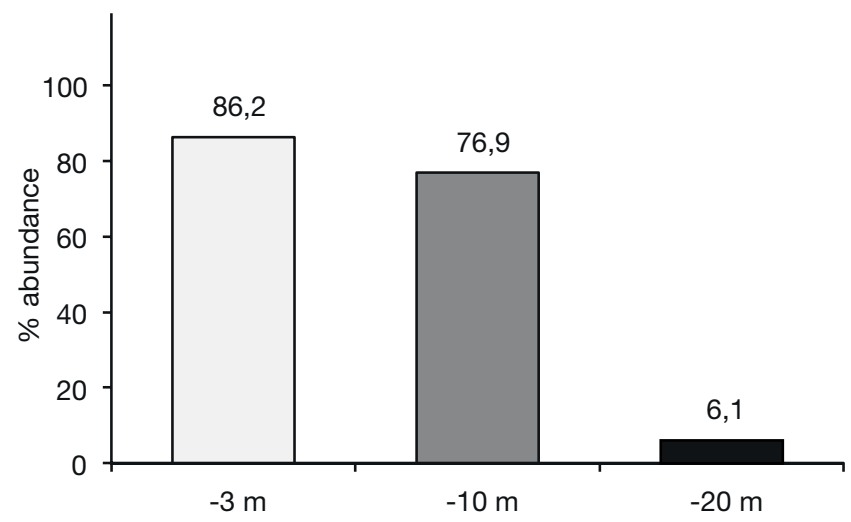

FIG. 1. - Percentage abundance of Ericaria brachycarpa (J. Agardh) MolinariNovoa \& Guiry at the sampling station estimated from 50 reticulated quadrats of $625 \mathrm{~cm}^{2}$ per depth.

TABLE 1. - Lineal fitting of the initial part of every Photosynthesis/PFD curve ( 0 to $85 \mu \mathrm{mol}$ photon $\mathrm{m}^{-2} \mathrm{~s}^{-1}$ ) where $\mathbf{a}$ is the slope of the fitted line (= photosynthetic efficiency), and interc. is the intercept; $\mathbf{p}<0.001^{(* *}$.

\begin{tabular}{lllllllll}
\hline Depth & $\mathbf{a} \pm \mathbf{s e}$ & & interc. & $\mathbf{\pm} \mathbf{s e}$ & $\mathbf{R}^{2}$ & $\mathbf{n}$ & $\mathbf{F}$ & $\mathbf{p}$ \\
\hline$-3 \mathrm{~m}$ & 0.057 & 0.004 & -0.87 & 0.20 & 0.92 & 20 & 205.4 & $* \star *$ \\
$-10 \mathrm{~m}$ & 0.053 & 0.004 & -0.74 & 0.17 & 0.92 & 18 & 183.1 & $* \star *$ \\
$-20 \mathrm{~m}$ & 0.088 & 0.004 & -1.77 & 0.22 & 0.96 & 20 & 423.7 & $* * *$ \\
\hline
\end{tabular}

TABLE 2. - Photosynthetic parameters ( $P_{\max }$ : photosynthesis at saturation, in $\mathrm{mg}$ $\mathrm{O}_{2} \cdot \mathrm{g}$ AFDW-1. $\mathrm{h}^{-1}$, I : light at saturation, in $\mu$ mol photon $\mathrm{m}^{-2} \mathrm{~s}^{-1}$, I $\mathrm{I}_{\mathrm{c}}$ : light at compensation, in $\mu$ mol photon $\left.\cdot \mathrm{m}^{-2} \cdot \mathrm{s}^{-1}\right)$, dark respiration $\left(\mathrm{R}_{\mathrm{d}}\right)$, in $\mathrm{mg} \mathrm{O}_{2} \cdot \mathrm{g} A F D W^{-1} \cdot \mathrm{h}^{-1}$.

\begin{tabular}{llllllll}
\hline Depth & $\mathbf{P}_{\max }$ & $\mathbf{\pm} \mathbf{s d}$ & $\mathbf{I}_{\mathbf{k}}$ & $\mathbf{I}_{\mathbf{c}}$ & $\mathbf{a}$ & $\mathbf{R}_{\mathbf{d}}$ & $\mathbf{\pm} \mathbf{~ s d}$ \\
\hline$-3 \mathrm{~m}$ & 6.24 & 1.33 & 124.3 & 15.2 & 0.057 & 0.50 & 0.11 \\
$-10 \mathrm{~m}$ & 6.02 & 1.28 & 126.6 & 13.9 & 0.053 & 0.45 & 0.13 \\
$-20 \mathrm{~m}$ & 7.65 & 1.50 & 107.2 & 20.1 & 0.088 & 1.00 & 0.14 \\
\hline
\end{tabular}

TABLE 3. - Results of one-way ANOVAs (depth) variables $P_{\max }$ and $R_{d}$, the Tukey test for the variable $P_{\max }$, and results of the two-way ANOVA (depth and light) and the Tukey test between species for the lineal part of the Photosynthesis/ PFD curves (a). Abbreviations: df, degrees of freedom; MS, mean squares; $\%$ var, percentage of explained variance; $\mathbf{p}$, signification level: non significant (ns), $\left.\mathrm{p}<0.05{ }^{(*)}, \mathrm{p}<0.011^{(*)}, \mathrm{p}<0.001^{(* \star}\right)$.

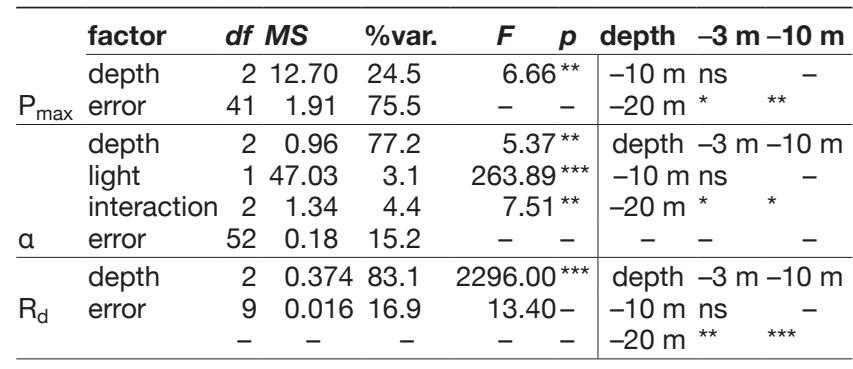

TABLE 4. - N:P, C:P and C:N ratios in algal (branch) tissues at different depths.

\begin{tabular}{cccc}
\hline Depth & N:P & C:P & C:N \\
\hline 3 & 45.7 & 2533.1 & 55.6 \\
10 & 36.2 & 1987.3 & 54.9 \\
20 & 42.3 & 2595.2 & 61.4 \\
\hline
\end{tabular}

specimens collected at 3 and $10 \mathrm{~m}$ are very similar and slightly different from specimens collected at $20 \mathrm{~m}$ (Fig. 2). The linear part of the P/PFD curves follows the same trend (Fig. 3), with a slightly steeper slope at $20 \mathrm{~m}$. Photosynthetic efficiency $(\alpha)$ is higher in specimens living at $20 \mathrm{~m}$ than at 10 and $3 \mathrm{~m}$ (Table 1), while $\mathrm{P}_{\max }, \mathrm{I}_{\mathrm{c}}$ and $\mathrm{R}_{\mathrm{d}}$ are also higher (Table 2). Differences between 10 and $3 \mathrm{~m}$ are never significant, while differences between 20 and 10 or $3 \mathrm{~m}$ are always significant (Table 3). $\mathrm{I}_{\mathrm{k}}$ is lower at $20 \mathrm{~m}$ than at 3 or $10 \mathrm{~m}$ (Table 2). N:P, C:N and C:P do not show any trend with depth (Table 4).

Regarding the transplant experiment we did not found significant differences between non-transplanted plants (controls nt3, nt20) and transplanted controls (3to3 and 20to20) ( $p>0.05$, t-Student). $P_{\text {sat }}, P_{b}$ and $R_{d}$ after 11 days and 90 days are presented in Fig. 4. Depth transplants (3to20 and 20to3) did not change significantly the $\mathrm{P}_{\text {sat }}$ after 11 days, not after 90 days (Fig. 4, Table 5). Depth transplants also did not significantly change the $\mathrm{P}_{\mathrm{b}}$ after 11 days (Table 5) but $\mathrm{P}_{\mathrm{b}}$ changed after 90 days, increasing for transplants from 3 to 20 and decreasing for transplants from 20 to 3 (Table 5). $R_{d}$ did not change after 90 days but differences were significant between transplants 3 to 20 and 20to 3 after 11 days (Table 5).

In general, photosynthesis (both at high and low light levels) and dark respiration increased from June to September (Fig. 4). Differences of $\mathrm{P}_{\text {sat }}$ between June and September were very important, explaining almost $70 \%$ of total variance for only $12.5 \%$ of variance associated to transplantation effects (Table 6). In contrast, the effect of transplantation explains $47 \%$ of total variance for $\mathrm{P}_{\mathrm{b}}$ and $\mathrm{R}_{\mathrm{d}}$ whilst seasonality only accounts for $11-13 \%$ (Table 6).

\section{DISCUSSION}

Specimens of E. brachycarpa living at $20 \mathrm{~m}$ show an adaptation to depth by increasing photosynthesis at saturation, light at compensation, and photosynthetic efficiency and by decreasing light at saturation. So, they are more efficient at using low light levels, require lower light levels to saturate photosynthesis, and reach higher photosynthetic rates if exposed to high light intensities. These patterns are exactly the same than those described by Sant \& Ballesteros (2020) when dealing with a wide range of aquatic macrophytes distributed along a bathymetric gradient. The increase in $\alpha$ is typical of macrophytes adapted to survive at low light conditions (Kirk 1994; Lobban \& Harrison 1994; Taiz \& Zeiger 1998) but this is not the case at $20 \mathrm{~m}$ in the Balearic islands where there is still plenty of light (Ballesteros \& Zabala 1993). The increase in $\mathrm{P}_{\max }$ should be also related to the general positive relationship between $\alpha$ and $P_{\max }$ described by Sant \& Ballesteros (2020) for Mediterranean macroalgae, meaning that there is a general pattern of adaptation to low light environments or decreasing light levels that spans at different taxonomical (across orders, families, genera and species) and population (within the same species) scales. This situation contrasts with results obtained when measuring photosynthetic features of blades of the same specimen of Macrocystis pyrifera (Linnaeus) C. Agardh distrib- 


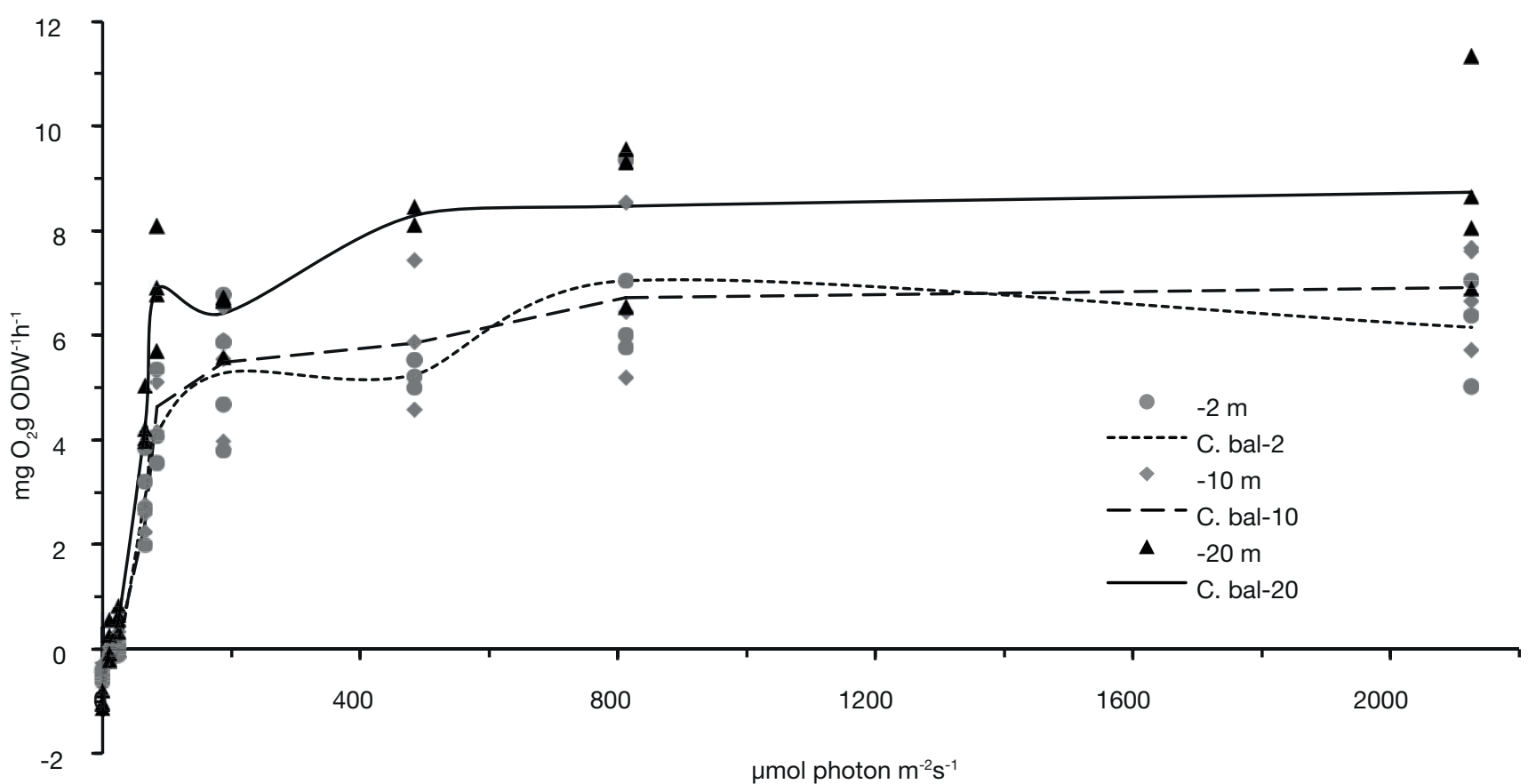

FIG. 2. - Photosynthesis/PFD curves for algal specimens collected at different depths.

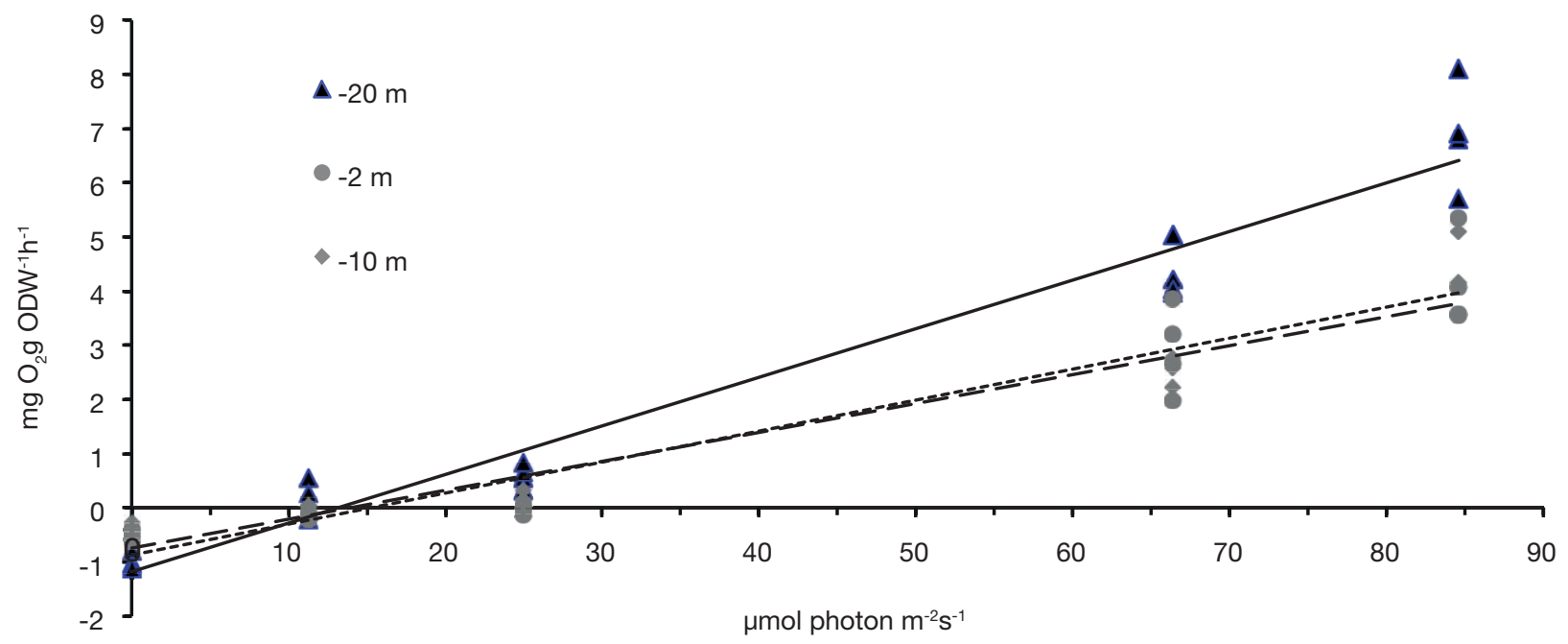

FIG. 3. - Lineal fitting of the photosynthesis/PFD data at the lineal part of the P/PFD curve for the algal specimens collected at different depths.

uted along a depth gradient (Colombo-Pallotta et al. 2006) where $\mathrm{P}_{\max }$ decreases with depth but still this can be perhaps explained by the high capacity of photoassimilates translocation of this species across the same individual (Parker 1963; Fox 2013), which does not occur when dealing with different individuals. Moreover Sant \& Ballesteros (2020) suggested that the higher $\mathrm{P}_{\max }$ and $\alpha$ found in deep-water species could be related to a higher nutrient content in tissues but here we do not find any outstanding differences between C:N, N:P or C:P ratios between depths, meaning that nutrients should not be as important as thought. This is consistent with the nutrient homogeneity found in waters above the thermocline, which is situated around 30 to $35 \mathrm{~m}$ depth in the Balearic islands (Ballesteros \& Zabala 1993).

Transplant experiments show that when specimens are transplanted from shallow to deep waters there is an increase in $\mathrm{P}_{\mathrm{b}}$ after 90 days but not in $\mathrm{P}_{\text {sat. }}$. Ramus et al. (1977) showed how Fucus vesiculosus Linnaeus and Ascophyllum nodosum (Linnaeus) Le Jolis increased both $\mathrm{P}_{\max }$ and $\alpha$ when transplanted at deeper environments and suggested that the macroalgae increase photosynthetic pigments but also the number of photosyntethic units (PSU; Ramus et al. 1977). Since there 

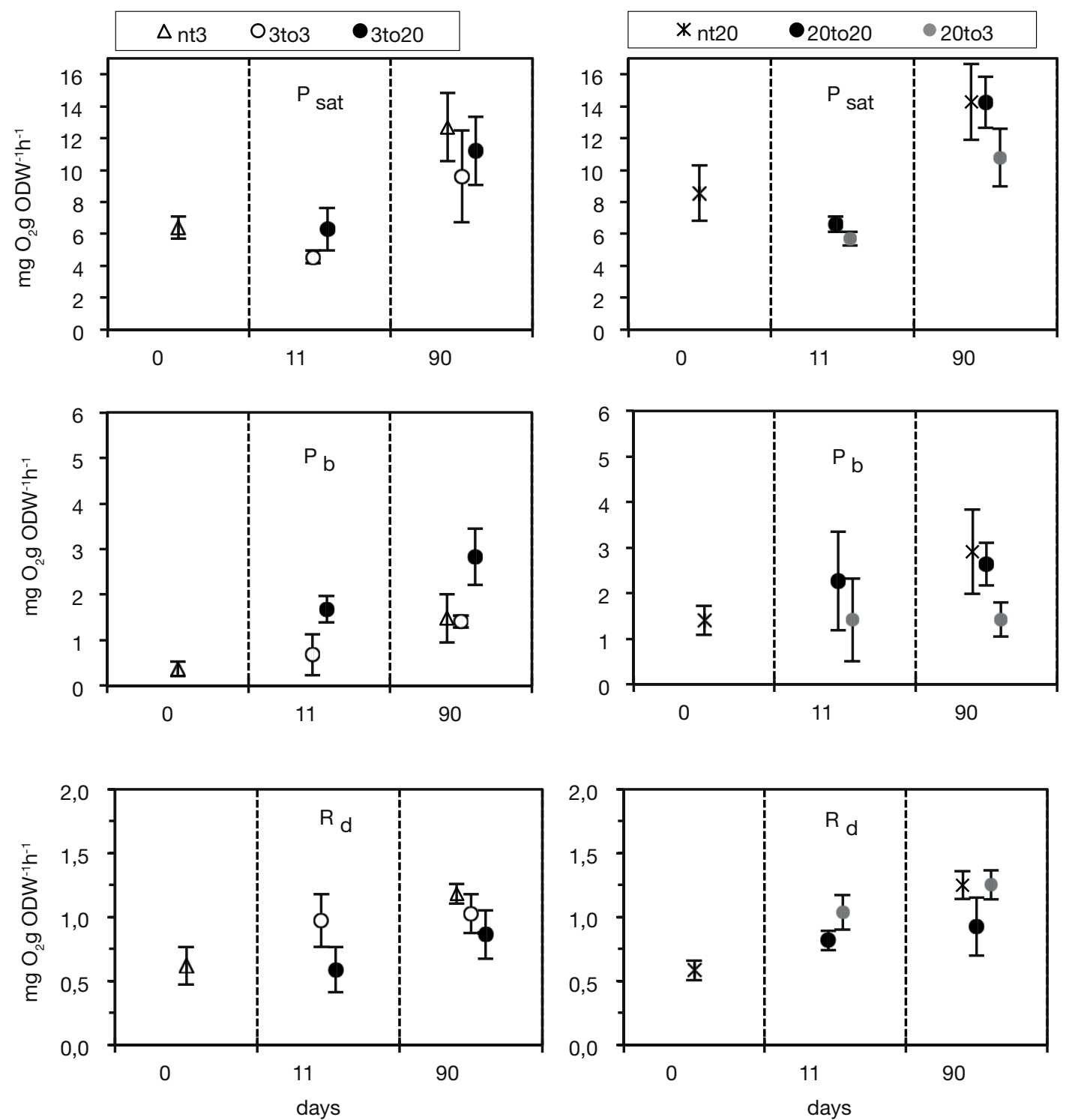

FIG. 4. - Photosynthesis at saturation $\left(P_{\text {sat }}\right)$, photosynthesis at low light levels $\left(P_{b}\right)$ and dark respiration $\left(R_{d}\right)$ for specimens thriving at 3 and $20 \mathrm{~m}($ not transplanted: nt3 and nt20) and for those transplanted at the same depth (3to3 and 20to20) and at different depths (3to20 and 20 to3) after 11 and 90 days after transplantation.

is no increase in $\mathrm{P}_{\text {sat }}$ in our experiments we suggest that E. brachycarpa is probably only increasing pigments and no PSU, which are needed to achieve higher photosynthetic rates at high light levels. Unfortunately we did not measure pigment concentrations and thus we do not have a response for this hypothesis. In fact, the increase of $\mathrm{P}_{\text {sat }}$ also involves changes in enzymes related to carboxilation mechanisms (Boardman 1977; Gerard 1988; Littler \& Littler 1992), which probably need longer time periods and are related to $\mathrm{N}$ availability (Ramus 1983; Peckol \& Ramus 1988).

Regarding transplants from deep to shallow waters, there is a decrease in $\mathrm{P}_{\mathrm{b}}$ after 90 days, which is consistent with the increase of $\mathrm{P}_{\mathrm{b}}$ reported before, when specimens were transplanted from shallow to deep waters. This means that photo- synthesis at low light levels, and hence $\alpha$, easily responds to changes in the light environment in such a way that individuals can use more efficiently the available light.

Another interesting result of the transplant experiment is the seasonal changes observed in both $\mathrm{P}_{\text {sat }}$ and $\mathrm{P}_{\mathrm{b}}$, as well as in dark respiration, which are always higher than the changes observed in depth transplants. As in other temperate seas, the light environment changes seasonally in the Mediterranean (Ballesteros 1992; Ballesteros \& Zabala 1993) and macroalgal physiology responds to this variation. In fact, Sant $\&$ Ballesteros (2020) reported a seasonal increase in $\mathrm{P}_{\max }$ and $\alpha$ from spring to autumn, which is consistent with our measures and with the light intensity decrease from June to September in the Mediterranean (Weinberg \& Cortel-Breeman 1978; Bal- 
TABLE 5. - Above: Results of one-way ANOVAs for variables photosynthesis at saturation $\left(P_{\text {sat }}\right)$, photosynthesis at low light levels $\left(P_{b}\right)$ and dark respiration $\left(R_{d}\right)$ after 11 and 90 days after transplant. Abbreviations: df, degrees of freedom; MS, mean squares; \%var, percentage of explained variance; $\mathbf{p}$, signification level. Below: Comparison (Tukey test) between transplants for each of the significant ANOVAs (*, above): non significant (ns), $p<0.05\left({ }^{*}\right)$.

\begin{tabular}{|c|c|c|c|c|c|c|c|c|c|c|c|c|c|}
\hline & 11 days & $d f$ & MS & \%var. & $\mathbf{F}$ & $\mathbf{p}$ & & 90 days & $d f$ & MS & \%var. & $\boldsymbol{F}$ & $p$ \\
\hline \multirow{2}{*}{$P_{\text {sat }}$} & transplant & 3 & 2.46 & 61.2 & 4.21 & $0.046^{*}$ & & transplant & 3 & 11.75 & 48.5 & 2.51 & 0.132 \\
\hline & error & 8 & 0.58 & 38.8 & - & - & & error & 8 & 4.68 & 51.5 & - & - \\
\hline \multirow[t]{2}{*}{$P_{b}$} & transplant & 3 & 1.31 & 46.1 & 2.28 & 0.156 & & transplant & 3 & 1.74 & 77.3 & 9.10 & $0.006^{\star}$ \\
\hline & error & 8 & 0.57 & 53.9 & - & - & & error & 8 & 0.19 & 22.7 & - & - \\
\hline \multirow[t]{2}{*}{$\mathrm{R}_{\mathrm{d}}$} & transplant & 3 & 0.12 & 64.5 & 4.85 & $0.033^{*}$ & & transplant & 3 & 0.09 & 51.5 & 2.83 & 0.106 \\
\hline & error & 8 & 0.03 & 35.5 & - & - & & error & 8 & 0.03 & 48.5 & - & - \\
\hline \multirow[t]{4}{*}{$P_{\text {sat }}$} & transplant & - & 3to3 & 3to20 & 20 to3 & - & $\mathrm{Pb}$ & transplant & - & 3to3 & 3to20 & 20to3 & - \\
\hline & 3to20 & - & ns & - & - & - & & 3to20 & - & * & - & - & - \\
\hline & 20to3 & - & ns & ns & - & - & & 20to3 & - & ns & * & - & - \\
\hline & 20to20 & - & * & ns & ns & - & & 20to20 & - & * & ns & * & - \\
\hline \multirow[t]{4}{*}{$\mathrm{R}_{\mathrm{d}}$} & transplant & - & 3to3 & 3 to20 & - & - & & & & & & & \\
\hline & 3to20 & - & ns & - & - & - & & & & & & & \\
\hline & 20to3 & - & ns & * & 20to3 & - & & & & & & & \\
\hline & 20to20 & - & ns & ns & ns & - & & & & & & & \\
\hline
\end{tabular}

lesteros 1992). Similar increases in maximum quantum yields in months with lower radiation levels have been found in the bull kelp, Durvillaea antarctica (Chamisso) Hariot (Tala et al. 2019). Another factor that could explain the seasonal differences in $\mathrm{P}_{\max }$ and $\alpha$ is the temperature that is known to affect photosynthesis in members of the order Fucales (Stengel \& Dring 1998; Murakami et al. 2004; Terada et al. 2018). In September, water temperature above the thermocline is $5^{\circ} \mathrm{C}$ higher than in June (Ballesteros \& Zabala 1993) but there is no data in the photosynthetic response of E. brachycarpa to temperature and thus, no conclusion can be drawn. Nevertheless, all the data obtained in this study and that provided by Sant \& Ballesteros (2020) points to the same direction: whenever there is a decrease in the amount of light -usually related to depth but also to season- Mediterranean algae respond by increasing photosynthetic efficiency and (usually) photosynthesis at saturation, as well as decreasing light at compensation. This means that the adaptation to the light environment of a population of macroalgae, in particular E. brachycarpa, depends both on depth and season. The plasticity of $E$. brachycarpa to adapt to the light environment suggests that the species can cope with small decreases in water transparency due to anthropogenic pressures such as sediment resuspension or chlorophyll increase in the water column related to nutrient uploads.

\section{Acknowledgements}

Diving permits were kindly provided by managers of the "Reserva Marina del Nord de Menorca” (Govern de les Illes Balears).

\section{REFERENCES}

Arenas F., Fernández C., Rico J. M., Fernández E. \& Haya D. 1995. - Growth and reproductive strategies of Sargassum muticum (Yendo) Fensholt and Cystoseira nodicaulis (Whit.) Roberts. Scientia Marina 59: 1-8.

BALlesteros E. 1986. - Métodos de análisis estructural en comunidades naturales, en particular del fitobentos. Oecologia Aquatica
TABLE 6. - Results of the two-way ANOVAs for variables $P_{\text {sat }}, P_{b}$ and $R_{d}$ considering factors "time" and "transplant". Abbreviations: df, degrees of freedom; MS, mean squares; \%var, percentage of explained variance; $\mathbf{p}$, signification level: non significant (ns), $p<0.05\left(^{(*)}, p<0.01\left(^{(*}\right), p<0.001\left(^{(\star *}\right)\right.$. $\mathrm{P}_{\text {sat }}, \mathrm{P}_{\mathrm{b}}$ and $\mathrm{R}_{\mathrm{d}}$ as in Table 5 .

\begin{tabular}{|c|c|c|c|c|c|c|}
\hline & factor & $d f$ & MS & \%var. & $\boldsymbol{F}$ & $p$ \\
\hline & time & 1 & 193.4 & 69.5 & 73.54 & *** \\
\hline & transplant & 3 & 11.6 & 12.5 & 4.41 & * \\
\hline & interaction & 3 & 2.6 & 2.8 & 1.00 & ns \\
\hline \multirow[t]{4}{*}{$P_{\text {sat }}$} & error & 16 & 2.6 & 15.1 & - & - \\
\hline & time & 1 & 1.89 & 11.0 & 4.93 & * \\
\hline & transplant & 3 & 2.69 & 47.0 & 7.03 & $\star \star$ \\
\hline & interaction & 3 & 0.36 & 6.3 & 0.95 & ns \\
\hline \multirow[t]{4}{*}{$\mathrm{P}_{\mathrm{b}}$} & error & 16 & 0.38 & 35.7 & - & - \\
\hline & time & 1 & 0.16 & 12.9 & 5.71 & * \\
\hline & transplant & 3 & 0.19 & 47.0 & 6.90 & ** \\
\hline & interaction & 3 & 0.02 & 3.8 & 0.56 & ns \\
\hline $\mathrm{R}_{\mathrm{d}}$ & error & 16 & 0.03 & 36.3 & - & - \\
\hline
\end{tabular}

8: $117-131$.

BAllesteros E. 1989. - Production of seaweeds in Northwestern Mediterranean marine communities: its relation with environmental factors. Scientia Marina 53: 357-364.

BALLESTEROS E. 1992. - Els vegetals i la zonació litoral: espècies, comunitats i factors que influeixen en la seva distribució. Arxius Secció Ciències Institut d'Estudis Catalans 101: 1-616.

Ballesteros E. \& Zabala M. 1993. - El bentos: el marc físic, in Alcover J. A., Ballesteros E. \& Fornós J. (eds), Història Natural de l'Arxipèlag de Cabrera: 663-685. CSIC-Ed. Moll, Palma de Mallorca.

Ballesteros E., Hereu B., Zabala M., Alcoverro T., GarRABOU J. \& SALA E. 2002. - Rapport mission Scandola: Cystoseira 2000. Travaux scientifiques du Parc naturel régional de la Corse 60: 95-115.

BOARDMAN N. K. 1977. - Comparative photosynthesis of sun and shade plants. Annual Review of Plant Physiology 28: 355377. https://doi.org/10.1146/annurev.pp.28.060177.002035

BOUdOURESQUe C. F. 1971. - Méthodes d'étude qualitative et quantitative du benthos (en particulier du phytobenthos). Téthys 3: 79-104.

BRINKHUIS B. H. 1985. - Growth patterns and rates, in LITTLER M. M. \& LitTLER D. S. (eds), Handbook of Phycological Methods. Ecological Field Methods: Macroalgae 22: 461-478. Cambridge University, Cambridge.

Catra M. \& Giardina S. 2009. — A survey of marine macroalgae 
of Karpathos Island (the Aegean Sea, Greece). Plant Biosystem 143: 509-515. https://doi.org/10.1080/11263500903172185

Cebrian E., Agell G., Martí R. \& Uriz M. J. 2006. — Response of the Mediterranean sponge Chondrosia reniformis Nardo to copper pollution. Environmental Pollution 141: 452-458. https:// doi.org/10.1016/j.envpol.2005.08.070

Cheminée A., Sala E., Pastor J., Bodilis P., Thiriet P., Mangialajo L., CotTAlorda J. M. \& Francour P. 2013. - Nursery value of Cystoseira forests for Mediterranean rocky reef fishes. Journal of Experimental Marine Biology and Ecology 442: 70-79. https://doi.org/10.1016/j.jembe.2013.02.003

Cheminée A., Pastor J., Bianchimani O., Thiriet P., Sala E., Cottalorda J. M., Dominici J. M., Lejeune P. \& FranCOUR P. 2017. - Juvenile fish assemblages in temperate rocky reefs are shaped by the presence of macro-algae canopy and its three dimensional structure. Scientific Reports 7: 14638. https:// doi.org/10.1038/s41598-017-15291-y

Cocito S., Bianchi C. N., Morri C. \& Peirano A. 2000 - - First survey of sessile communities on subtidal rocks in an area with hydrothermal vents: Milos island, Aegean Sea. Hydrobiologia 426: 113-121. https://doi.org/10.1023/A:1003991117108

Colombo-Pallotta M. F., García-Mendoza E. \& Ladah L. 2006. - Photosynthetic performance, light absorption, and pigment composition of Macrocystis pyrifera (Laminariales, Phaeophyceae) blades from different depths. Journal of Phycology 42: 1225-1234. https://doi.org/10.1111/j.1529-8817.2006.00287.x

Coppejans E. \& Boudouresque C. F. 1975. - Sur la richesse floristique de certains peuplements photophiles infralittoraux de Port-Cros (Var, France). Rapports et Procès Verbaux de la Commission Internationale pour l'Exploration Scientifique de la Mer Méditerranée 23: 79-80.

Cormaci M., Furnari G., Catra M., Alongi G. \& Giaccone G. 2012. - Flora marina bentonica del Mediterraneo, Phaeophyceae. Bollettino dell'Accademia Gioenia Scienze Naturale 45: 1-508.

EINAV T. \& ISRAEL A. 2008. - Cheklist of seaweeds from the Israeli Mediterranean: Taxonomical and ecological approaches. Israel Journal of Plant Sciences 56: 127-191. https://doi.org/10.1560/ IJPS.57.1-2.127

ERCEGOVIC A. 1952. - Sur les Cystoseira adriatiques: leur morphologie, écologie et évolution. Fauna et Flora Adriatica 2: 1-212.

Fox M. D. 2013. - Resource translocation drives ${ }^{13} \mathrm{C}$ fractionation during recovery from disturbance in giant kelp, Macrocystis pyrifera. Journal of Phycology 49: 811-815. https://doi.org/10.1111/ jpy. 12099

GERARD V. A. 1988. - Ecotypic differentiation in light-related traits of the kelp Laminaria saccharina. Marine Biology 97: 25-36. https://doi.org/10.1007/BF00391242

GiaCCONE G. 1973. - Écologie et chorologie des Cystoseira de Mediterranée. Rapports et Procès Verbaux de la Commission Internationale pour l'Exploration Scientifique de la Mer Méditerranée 22: 49-50.

Giakoumi S., Cebrian E., KokKoris G. D., Ballesteros E. \& SALA E. 2012. - The structure of shallow rocky sublittoral communities in the Cyclades, Eastern Mediterranean: relationships between fish, sea urchins and macroalgae. Estuarine Coastal and ShelfScience 109: 1-10. https://doi.org/10.1016/j.ecss.2011.06.004

GÓMEZ I. \& WieNCKE C. 1997. — Seasonal growth and photosynthetic performance of the Antarctic macroalga Desmarestia menziesii (Phaeophyceae) cultured under fluctuating Antarctic daylengths. Botanica Acta 110: 25-31. https://doi. org/10.1111/j.1438-8677.1997.tb00607.x

GÓmez I., Wiencke C. \& ThOMAS D. N. 1996. — Variations in photosynthetic characteristics of the Antarctic marine brown alga Ascoseira mirabilis Skottsberg in relation to age and size. European Journal of Phycology 31: 167-172. https://doi. org/10.1080/09670269600651341

Gómez-Garreta A., Ribera M. A., Barceló M. C. \& Ruli LLUCH J. 1994. - Mapas de distribución de algas marinas de la Península Ibérica e Islas Baleares. V. Cystoseira C. Agardh: gru- pos C. ericaefolia y C. crinito-selaginoides. Botanica Complutensis 19: $109-118$

Hoffmann L., Renard R. \& Demoulin V. 1992. - Phenology, growth and biomass of Cystoseira balearica in Calvi (Corsica). Marine Ecology Progress Series 80: 249-254. https://doi. org $/ 10.3354 / \mathrm{meps} 080249$

Huvê H. 1972. - Aperçu sur la distribution en Mer Egée de quelques espèces du genre Cystoseira (Phéophycées, Fucales). Bulletin de la Societé Phycologique de France 17: 22-37.

Ivesa L., Djakovac T. \& Devescovi M. 2016. — Long-term fluctuations in Cystoseira populations along the west Istrian Coast (Croatia) related to eutrophication patterns in the northern Adriatic Sea. Marine Pollution Bulletin 106: 162-173. https:// doi.org/10.1016/j.marpolbul.2016.03.010

Jones C. T., Craig S. E., Barnett A. B., Macintyre H. L., CulLEN J. J. \& RAVEN J. 2014. - Curvature in models of the photosynthesis/irradiance response. Journal of Phycology 41: 223-233.

KIRK J. T. O. 1994. - Light and photosynthesis in aquatic ecosystems. Cambridge University, Cambridge, 509 p.

LAKKIS S. \& NOVEL-LAKKIS V. 2000. — Distribution of phytobenthos along the coast of Lebanon. Mediterranean Marine Science 1: 143-164. https://doi.org/10.12681/mms.295

LiTTLER M. M. 1979. - The effects of bottle volume, thallus weight, oxygen saturation levels, and water movement on apparent photosynthetic rates in marine algae. Aquatic Botany 7: 21-34. https://doi.org/10.1016/0304-3770(79)90004-4

LiTTLER M. M. \& ARNOLD K. E. 1980. - Sources of variability in macroalgal primary productivity: sampling and interpretative problems. Aquatic Botany 8: 141-156. https://doi.org/10.1016/03043770(80)90046-7

LiTTLER M. M. \& LiTTLER D. S. 1985. - Handbook of Phycological Methods. Ecological Field Methods: Macroalgae. Cambridge University, Cambridge, 617 p.

LitTLER M. M. \& LiTTLER D. S. 1992. - Photosynthesis vs. irradiance curves for six species of macroalgae from the Seychelles Islands under four levels of nutrient enrichment. Atoll Research Bulletin 374: 1-14. https://doi.org/10.5479/si.00775630.374.1

LOBban C. S. \& HarrisOn P. J. 1994. - Seaweed Ecology and Physiology. Cambridge University, Cambridge, 366 p.

MATEO M. A. \& SABATÉ S. 1993. - Wet digestion of vegetal tissue using a domestic microwave oven. Analytica Chimica Acta 279: 273-279. https://doi.org/10.1016/0003-2670(93)80326-G

Molinari-Novoa E. A. \& GUIRY M. D. 2020. — Reinstatement of the genera Gongolaria Boehmer and Ericaria Stackhouse (Sargassaceae, Phaeophyceae). Notulae Algarum 172: 1-10.

Montesanto B. \& Panayotidis P. 2000. - The Cystoseira spp. communities from the Aegean Sea (north-east Mediterranean). Journal of the Marine Biological Association of the United Kingdom 80: 357-358. https://doi.org/10.1017/S0025315400001946

Murakami H., Serisawa Y., Kurashima A. \& Yokohama Y. 2004. - Photosynthetic performances of temperate Sargassum and kelp species growing in the same habitat. Algae 19: 207-216. https://doi.org/10.4490/ALGAE.2004.19.3.207

PARKER B. C. 1963. - Translocation in the giant kelp Macrocystis. Science 140: 891-892. https://doi.org/10.1126/science.140.3569.891

Peckol P. \& Ramus J. 1988. - Abundances and physiological properties of deep-water seaweeds from Carolina outer continental shelf. Journal of Experimental Marine Biology and Ecology 115: 25-39. https://doi.org/10.1016/0022-0981(88)90187-6

Piazzi L., Balata D. \& Ceccherelli G. 2017. — Resilience of Cystoseira beds: lack of canopy effects on recruitment. Botanica Marina 60: 49-53. https://doi.org/10.1515/bot-2016-0088

Piazzi L., Bonaviri C., Castelli A., Ceccherelli G., Costa G., Curini-Galletti M., Langeneck J., Manconi R., Montefalcone M., Pipitone C., Rosso A. \& Pinna S. 2018. — Biodiversity in canopy-forming algae: Structure and spatial variability of the Mediterranean Cystoseira assemblages. Estuarine, Coastal and Shelf Science 207: 132-141. https://doi.org/10.1016/j. 
ecss.2018.04.001

Piazzi L. \& CeCCHerelli G. 2017. - Concomitance of oligotrophy and low grazing pressure is essential for the resilience of Mediterranean subtidal forests. Marine Pollution Bulletin 123: 197-204. https://doi.org/10.1016/j.marpolbul.2017.08.061

RAMUS J. 1983. - A physiological test of the theory of complementary chromatic adaptation, II. Brown, green and red seaweeds. Journal of Phycology 19: 173-178. https://doi.org/10.1111/j.00223646.1983.00173.x

Ramus J., LEMONS F. \& Zimmerman C. 1977. - Adaptation of light-harvesting pigments to downwelling light and the consequent photosynthetic performance of the eulittoral rockweeds Ascophyllum nodosum and Fucus vesiculosus. Marine Biology 42 293-303. https://doi.org/10.1007/BF00402191

Ribera M. A., Gómez-Garreta A., Barceló M. C. \& Ruli LluCH J. 1995. - Mapas de distribución de algas marinas de la Península Ibérica e Islas Baleares. VIII. Cystoseira C. Agardh y Sargassum C. Agardh. Botanica Complutensis 20: 89-103.

Rodríguez-Prieto C., Ballesteros E., Boisset F. \& AfonsoCARrillo J. 2013. - Guía de las macroalgas y fanerógamas marinas del Mediterráneo Occidental. Omega, Barcelona, 656 p.

ROMERO J. 1981. — Biomasa de comunidades de algas bentónicas de las islas Medes (Girona). Oecologia Aquatica 5: 87-93.

Sala E. \& Ballesteros E. 1997. — Partitioning of space and food resources by three fishes of the genus Diplodus (Sparidae) in a Mediterranean rocky infralittoral ecosystem. Marine Ecology Progress Series 152: 273-283. https://doi.org/10.3354/meps 152273

Sales M. \& Ballesteros E. 2009. — Shallow Cystoseira (Fucales: Ochrophyta) assemblages thriving in sheltered areas from Menorca (NW Mediterranean): relationships with environmental factors and anthropogenic pressures. Estuarine, Coastal and Shelf Science 84: 476-482. https://doi.org/10.1016/j.ecss.2009.07.013

Sales M., Cebrian E., Tomas F. \& Ballesteros E. 2011. - Pollution impacts and recovery potential in three species of the genus Cystoseira (Fucales, Heterokontophyta). Estuarine, Coastal and Shelf Science 92: 347-357. https://doi.org/10.1016/j.ecss.2011.01.008

SANT N. 2003. - Algues bentòniques mediterrànies: comparació de mètodes de mostreig, estructura de comunitats $i$ variació en la resposta fotosintética. Tesis Doctoral, Universitat de Barcelona, 250 p.

SANT N. \& BAllesteros E. 2020. - Photosynthetic activity of macroalgae along a bathymetric gradient: interspecific and seasonal variability. Scientia Marina 84: 7-16. https://doi.org/10.3989/ scimar.04995.06A

Sant N., Chappuis E., Rodríguez-Prieto C., Real M. \& BalLESTEROS E. 2017. - Cost-benefit of three different methods to study Mediterranean rocky assemblages. Scientia Marina 81 : 129-138. https://doi.org/10.3989/scimar.04463.04A

STENGEL D. B. \& DRING M. J. 1998. - Seasonal variation in the pigment content and photosynthesis of different thallus regions of Ascophyllum nodosum (Fucales, Phaeophyta) in relation to position in the canopy. Phycologia 37: 259-268. https://doi. org/10.2216/i0031-8884-37-4-259.1

TAIZ L. \& Zeiger E. 1998. — Plant physiology. Sinauer Associates Inc., Sunderland, 792 p.

Tala F., Penna-Díaz M. A., Luna-Jorquera G., Rothausler E. \& THIEL M. 2019. - Daily and seasonal changes of photobiological responses in floating bull kelp Durvillaea antarctica (Chamisso) Hariot (Fucales: Phaeophyceae). Phycologia 56: 271-283. https:// doi.org/10.2216/16-93.1

Tamburello L., Ravaglioli C., Mori G., Nuccio C. \& BulLERI F. 2019. - Enhanced nutrient loading and herbivory do not depress the resilience of subtidal canopy forests in Mediterranean oligotrophic waters. Marine Environmental Research 149: 7-17. https://doi.org/10.1016/j.marenvres.2019.05.015

TAskin E., Jahn R., ÖZTURK M., Furnari G. \& Cormaci M. 2012. - The Mediterranean Cystoseira (with photographs). Celal Bayar University Publications 4: 1-75.

Terada R., Matsumoto K., Borlongan I. A., Watanabe Y., Nishihara G. N., Endo H. \& Shimada S. 2018. - The combined effects of PAR and temperature including the chilling-light stress on the photosynthesis of a temperate brown alga, Sargassum patens (Fucales), based on field and laboratory measurements. Journal of Applied Phycology 30: 1893-1904. https://doi. org/10.1007/s10811-017-1344-7

Thibaut T., Blanfuné A., Boudouresque C. F., Cottalorda J. M. Hereu B., Susini M. L. \& Verlaque M. 2016. — Unexpected temporal stability of Cystoseira and forests in Port-Cros, one of the oldest Mediterranean marine National Parks. Cryptogamie, Algologie 37: 61-90. https://doi.org/10.7872/crya/v37.iss1.2016.61

Thiriet P. D., Di Franco A., Cheminée A., Guidetti P., Bianchimani O., Basthard-Bogain S., Cottalorda J. M., Arceo H., Moranta J., Lejeune P., Francour P. \& Mangialajo L. 2016. - Necto-benthic coastal fish are higher in marine forests than in structurally less complex macroalgal assemblages. PLoS ONE 11(10): e0164121.

Tomas F., Cebrian E. \& Ballesteros E. 2011. — Differential herbivory of invasive algae by native fish: temporal and spatial variability. Estuarine, Coastal and ShelfScience 92: 27-34. https:// doi.org/10.1016/j.ecss.2010.12.004

UnEP/MAP 2009. - Report of the 16th Ordinary Meeting of the Contracting Parties to the Convention for the Protection of the Marine Environment and the Coastal region of the Mediterranean and its Protocols, Marrakesh, Morocco, 3-5 November 2009, UNEP and Mediterranean Action Plan, Athens, $321 \mathrm{p}$

Vergés A., Alcoverro T. \& BAllesteros E. 2009. - Role of fish herbivory in structuring the vertical distribution of canopy algae (Cystoseira spp.) in the Mediterranean Sea. Marine Ecology Progress Series 375: 1-11. https://doi.org/10.3354/meps07778

VerLaQue M. 1987. - Contribution à l'étude du phytobenthos d'un ecosystème photophile termophile en Méditerranée Occidentale. PhD. Univ. d'Aix-Marseille, 389 p.

Verlaque M., Boudouresque C. F. \& Perret-Boudouresque M. 2019. - Mediterranean seaweeds listed as threatened under the Barcelona Convention: A critical analysis. Scientific Reports PortCros National Park 33: 179-214.

Weinberg S. \& Cortel-BreEman A. 1978. - The estimation of the yearly cycle of submarine irradiance for ecological purposes: A methodological example based on data from Banyuls sur Mer. Bijdragen tot de Dierkunde 48: 35-44. https://doi org/10.1163/26660644-04801004

WITMAN J. D. \& DAYTON P. K. 2001. — Rocky subtidal communities, in Bertness M. D., Gaines S. D. \& Hay M. E. (eds), Marine Community Ecology: 339-366. Sinauer Associates, Sunderland.

Zabala M. \& BALleSTEROS E. 1989. — Surface-dependent strategies and energy flux in benthic marine communities or, why corals do not exist in the Mediterranean. Scientia Marina 53: 1-15. 